\title{
Attaining Content and Language Integrated Learning (CLIL) in the Primary School Classroom
}

\author{
Nancy Bailey* \\ Teacher Trainer for the Italian Ministry of Education In-service Further Education Programs in Italy \\ *Corresponding author: redigranbailey@yahoo.it
}

Received March 16, 2015; Revised March 18, 2015; Accepted March 19, 2015

\begin{abstract}
In consideration of the need for pupils to start using English as a second language (L2) beyond the 2-3 hour a week compulsory "English lesson" in Italian primary schools, the new Italian National Curriculum Guidelines encourage multilingual education. This official stimulus could lead to the achievement of a more bilingual classroom with increased usage of English throughout the school day, especially through the use of Content and Language Integrated Learning (CLIL) strategies. However, teachers are often at a loss as to how to accomplish this. They must be helped to realize that it can be easier than they think, especially through the use of new technologies, and in spite of what they consider to be inadequate preparation. They need clear, practical indications of easy, brief activities that they can carry out daily in English in their classrooms in the various subject areas and they need to be familiar with the multimedia opportunities that exist to achieve this goal. This experimental project presents practical, flexible materials and ideas that can be used to introduce topics or to revise contents in all subjects while encouraging the use of L2 instead of Italian (L1). The materials developed can be easily adapted for use in other foreign languages (L2) and in lower secondary education for a third foreign language (L3) (CEFR 0-A1). This CLIL project aims to facilitate primary school teachers' introduction of English into all subjects. This paper was presented at the 9th International CLIL Conference, Think CLIL 2014, Ca' Foscari University of Venice, Venice, Italy, 28-30 August 2014.
\end{abstract}

Keywords: Elementary School/ Teacher Education/ CLIL/ Cross-Disciplinary Areas of Education/ Language Education/ ESL

Cite This Article: Nancy Bailey, "Attaining Content and Language Integrated Learning (CLIL) in the Primary School Classroom.” American Journal of Educational Research, vol. 3, no. 4 (2015): 418-426. doi: 10.12691/education-3-4-6.

\section{Introduction}

What does Content and Language Integrated Learning (CLIL) involve?

CLIL concerns teaching various school subjects through a foreign or second language (L2), which can be carried out by the L2 teacher or by the subject teacher using the L2. The term CLIL was coined by David Marsh in 1994:

"CLIL refers to situations where subjects, or parts of subjects, are taught through a foreign language with dualfocused aims, namely the learning of content, and the simultaneous learning of a foreign language."

CLIL is often used as an umbrella term covering various educational approaches (e.g. language immersion, bilingual education, multilingual education, language across curriculum, etc.). What is new about CLIL is that it provides a more flexible way of using two languages in the classroom, allowing for low- to high-intensity exposure to teaching/learning through a second language.

Of course, CLIL involves consequences for classroom methodology. The British Council recommendations (2014) on CLIL state:
"When learning through CLIL, where an additional language is used, language-supportive resources, methods and activities are actively and coherently used to enable learners to use language purposefully. This support acts as a form of scaffolding enabling learners to effectively process information, negotiate understanding, and coconstruct knowledge even where a cohort has a heterogeneous level of fluency in the vehicular language....

Recommendation 7: Emphasis on methodologies and not only language development in both initial and inservice teacher education programmes. Good CLIL practices are widely reported as being based, in part, on socio-constructivist teaching and learning methods and activities. Any CLIL professional development should aspire to combine language development and methodological competence in interactive teaching and learning approaches.”

In fact, CLIL places more focus on procedural skills to get across conceptual contents, thus the teacher must become more aware of the processes that the students need to master in order to assimilate the contents. In other words, there is no separation, in CLIL, of the spheres of concepts, procedures and language.

One of the advantages of using CLIL methodology in the classroom is that it can provide exposure to L2 without 
requiring extra time in the curriculum, although teachers must adapt their style of teaching to allot for L2 deficiencies as compared with L1 skills.

David Graddol (2006) wrote that CLIL

"...differs from simple English-medium education in that the learner is not necessarily expected to have the English proficiency required to cope with the subject before beginning study."

Teachers have to adjust their methodology to ensure that the students understand the contents.

Their educational materials also have to reflect this approach and teachers have to adapt existing materials or design their own in order to work within a more languageenhanced paradigm suitable for a mixed-ability class. This involves more hands-on, task-based lessons alongside collaborative learning and group work. When applied correctly, this leads to a reduction in teacher-talk and an increase in student-talk creating a more learner-centered environment. Of course, with practice, teachers gradually become skilled at anticipating language problems and the process of planning lessons to overcome them becomes more routine.

Some synthetic, basic support strategies have been outlined by John Clegg:

"Support strategies for listening: To help learners listen, subject teachers highlight or explicitly teach vocabulary. At the text level they help learners to follow them by using visuals and by adjusting their talking style: they enumerate points, give examples, explain, summarise, more than they would in L1.

Support strategies for speaking: To help students talk in the plenary classroom, they adjust their questions (asking, perhaps, some cognitively demanding but short answer questions); they prompt (for example they start learners' responses for them); they provide vocabulary, they may allow some L1 responses. To help them talk in groups, they provide support at the word level by listing key words to use; to help with making sentences they can offer supportive task types such as talking frames, sentence starters or substitution tables; or they ask students to use their L1 when discussing but their L2 when reporting.

Support strategies for reading: To help students with reading they may check that they understand key vocabulary before they read; they may provide them with pre-reading questions to reduce the reading demands of the text; or they may offer help at the text level by giving reading support tasks, such as a chart to fill in, a diagram to label, etc.

Support strategies for writing: To help them with writing, they can offer support at all three levels by providing a vocabulary list, sentence starters, or a writing frame. They can also ensure that the learners talk through their writing at the word, sentence and text level, with each other, probably in L1, before they write.”

Especially at the beginning, it is important for subject teachers to collaborate with language teachers. Language teachers already possess most of these skills which are regularly used in teaching $\mathrm{L} 2$.

One aspect of CLIL which should not be underestimated is that it is highly motivating to students who view the practical application of L2 as a vehicular language in coping with complex concepts as a communicative skill that they will need in their futures.
The development of competences is much more likely to occur within an approach that prioritizes thinking skills and communication.

It has been said that (Marsh, Marsland and Stenberg, 2001): "CLIL is about using languages to learn... It is about installing a 'hunger to learn' in the student. It gives opportunity for him/her to think about and develop how s/he communicates in general, even in the first language."

According to psycholinguists, the more that higher operations are involved in a task, the greater the probability of linguistic retention. The higher the level of thinking involved, the more likely the assimilation of the vehicular language (Ball, 2013).

\section{CLIL in Italy}

Primary School teacher training in Italy has been undergoing important changes since the introduction of the new Italian National Curriculum Guidelines for ages three to fourteen in 2013 (Ministero dell'Istruzione, dell'Università e della Ricerca). These guidelines offer greater opportunities now for the use of English as a Second Language (L2) in Italian classrooms, especially in Primary Schools, since they encourage the occasional use of L2 throughout the school day across the curricula, instead of only during the 'English period.' This is in adherence to the norms outlined in the EU Common European Framework of Reference (CEFR) for all foreign language learning, teaching and assessment (Council of Europe, 2011).

In addition, recently most Italian public Primary Schools (5 years from ages 6 to 10) and public Middle Schools (3 years from ages 11 to 14 ) have been united into Comprehensive Schools, providing the increased possibilities of curricular continuity throughout the first 8 years of compulsory schooling (Ministero dell'Istruzione, dell’Università e della Ricerca, 2014).

The new National Guidelines invite teachers and schools to

- overcome the fragmentation or division of different subjects and to intertwine the various subject areas;

- prioritize plurilingual and multicultural education;

- create situations in which the second and third foreign language (L2/L3) is used, instead of Italian (L1), to promote and to guide learning in the various subjects.

Furthermore, the Guidelines declare that it is the responsibility of all teachers to help pupils master their L1 but at the same time also bolster local dialects, L2 and L3.

The ideal solution for enacting these guidelines is the application of Content and Language Integrated Learning (CLIL) (Coyle, Hood and Marsh, 2010) (Coonan, 2014). CLIL has been identified as very important by the European Commission because: "It opens doors on languages for a broader range of learners, nurturing selfconfidence in young learners... It provides exposure to the language without requiring extra time in the curriculum..." The European Commission has therefore decided to promote the training of teachers leading to "enhancing the language competences in general, in order to promote the teaching of non-linguistic subjects in foreign languages" (2003). However, Italian primary school teachers, who have recently had to replace the specialized English 
teachers and who now find themselves having to teach and use English in their classes for the first time, are often at a loss as to how to accomplish this. This innovation affects 246,874 primary school teachers (Italian National Bureau of Statistics, ISTAT, 2013). The majority of these do not have the required CEFR B1 minimum level in English required by the Ministry of Education to teach it as L2 in their classes (Council of Europe, 2011). Thus, in addition to the in-service training courses offered by the Ministry, these teachers must also be helped to realize that using English in the classroom can actually be easier than they think, especially with the availability of new technologies, and in spite of what they consider to be their inadequate preparation and a low level of knowledge of English. They need clear, practical indications of brief activities that they can carry out daily in their classrooms in the various subject areas and they need to be familiar with the resources that exist in order to achieve this goal.

\section{In the Classroom}

The author has been conducting the above-mentioned training courses for several years in Tuscany, Italy, as well as working alongside teachers helping them to apply appropriate methods leading to the wider use of L2 in the classroom, which, in turn, results in their pupils' learning more English.

The primary and basic principles that teachers must acknowledge in order to be effectual are that:

1. there is NO reason NOT to use English in the classroom;

2. ten minutes of English three times a day is much more effective than one hour two or three times a week;

3. English can easily be used to consolidate or review curriculum, which has been taught in L1, in an interesting, fun way.

There are five language skills that need to be developed in language learning (Council of Europe, 2011) which can also be used in CLIL:

1. listening comprehension;

2. oral production;

3. reading;

4. writing;

5. interaction, communication, or, as Merrill Swain (2006) terms it, "languaging."

This last point includes:

- classroom commands (e.g. please stand up / sit down, open your book / close your book, come here / go to..., be quiet / don't talk, ask / answer, write ... / read..., look (at) / listen / repeat, touch / don’t touch, draw / color / cut/ fold / point (to) / match, etc.);

- social interaction (e.g. Good morning/afternoon, Hello /Hi, How are you?, Please, Thank you, Very good, Well done!, OK, That's (not) right, Goodbye / Bye bye, Have a nice weekend! etc.);

- pupils' answers and questions (e.g. Can I go to the toilet, please? Can I give this to ...? Can I open the window? Can I finish at home? Can I work with...? Can I be in that group?, etc.);

- interaction among the pupils (e.g. Can I have that, please? Where is the...? What's wrong?, Is this correct?, etc.)
- natural exclamations (e.g. Stop it! Oh, no! You can't do that! Please be quiet!)

To obtain the best results, teachers must keep an updated list of the vocabulary/expressions used in the classroom and share it with all the teachers working with the class so as to facilitate their continuation of interaction in $\mathrm{L} 2$.

One helpful tool is to create a bilingual classroom with interactive posters containing:

-all time expressions (calendar: date, day of the week, months, seasons, time of day, year)

- cardinal and ordinal numbers,

- the most common adjectives (e.g. emoticons),

- school subjects,

- classroom rules,

- food and drink,

- common animals,

- weather, etc.

These are also very useful with immigrant children who have a different L1.

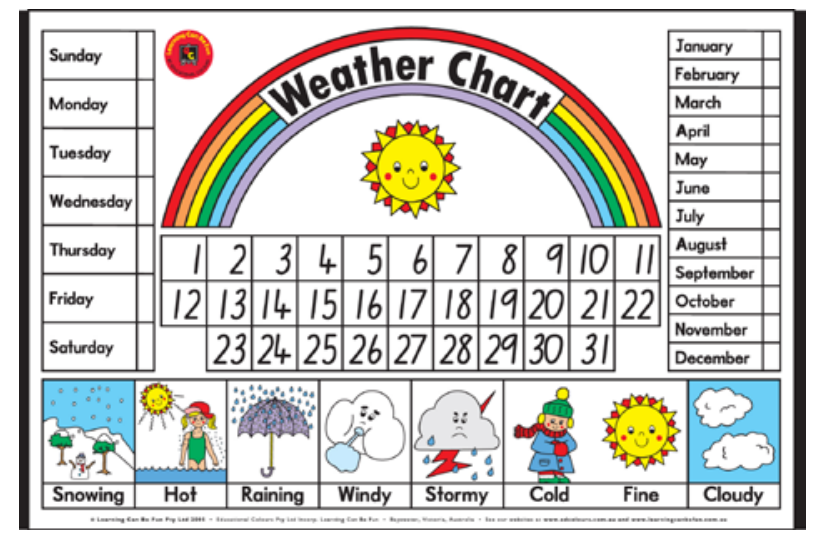

Alongside these, teachers should put up five dynamic posters in their classrooms. A dynamic poster is one that can be added to when new relevant elements are discovered, which also provides the occasion to revise previous terms each time.

These should include the following information, in this case comparing English/L2 and Italian/L1:

1. English words used in Italian: weekend, bus, tennis, clown, party, star, sport...

2. Italian words used in English: cappuccino, espresso, pasta, tortellini, ravioli, lasagna, spaghetti, macaroni, pizza, prosciutto, mafia, bandito...

3. Cognates (words which are similar to L1 with the same meaning in L2): student, class, vote, detective, cartoon...

4. False friends (words which are similar to or used in L1 but that have a different meaning in L2): bar, box, golf, toast, camera, library, magazine...

5. International words used in both English and Italian: video, radio, saliva, influenza, orchestra, banana, cinema, formula, stereo, garage, tennis, CD, DVD, film, picnic, shampoo, tablet, quiz ...

The teachers and I have been very surprised by the fact that children do not recognize the English words used in Italian as non-Italian words. The importance of creating these posters is that these are words which the pupils already know and can therefore use freely, increasing their potential of expressing themselves more naturally and completely in L2. 
Essential tools for the classroom teacher whose mother tongue is not the target L2 are the new apps and websites which exist for immediate translation from L2 into L1 and which also provide the correct pronunciation of the L2 terms (e.g. Google translate: https://translate.google.com). All that is needed is internet and a mobile phone. Of course, those lucky enough to have Smart Boards, computers, or tablets are at an advantage.

\section{Fast and Easy CLIL Activities}

One of the most valid ways we have found for increasing active vocabulary, which can then be used in CLIL, is through songs and games which are also fun for the children. The very best is 'Simon says' which should be played at least once a week (5 -10 minutes), adding new verbs and variations each time. For maximum efficacy teachers have to remember to keep an updated list of the commands which they can share with other teachers working with the class.

Other examples are action songs which embody Total Physical Response. Total physical response (TPR) is a language teaching method developed by James Asher (1969), based on the coordination of language and physical movement. In TPR, instructors give commands to students in the target language, and students respond with whole-body actions, also giving them the possibility to stand up and stretch (e.g. parts of the body songs, such as the classics: Head and shoulders, Hokey Pokey, This is the way I/we wash my/our hands, etc., - numerous versions are available on YouTube). These can also be CLIL activities with Physical Education and Music Education.

Passing now from language learning to language usage in other subjects, let's examine the opportunities offered by CLIL in actively using L2 in learning or revising contents in different subject areas. Most CLIL projects in Italy are usually valid but often elaborate and long-term. However, CLIL activities can also be fast and easy and inserted into school programs all day long, thereby exponentially increasing the time pupils spend using English to communicate.

\subsection{Math/arithmetic}

Some examples to use with smaller children:

- Invent raps using numbers: 1-2-345, 1-2-345, 1-2345, 12345;

- 5-4-321, 5-4-321, 5-4-321, 54321

- Use numbers for marching to a different classroom, to lunch, etc.

- Doing Math: 1 and 1 is 2, 1 minus 1 is 0

- Number chains: forward and backward around the class

- Songs: “Ten Little Indians/Tigers” “10 Green Bottles”

- Games: Drop the Hanky (if you are in a gym or outside) or 'Stand up first when your number is called' (if you are doing it in the classroom)

- Number the students then with rhythm, they first say their own number then that of another (who isn't 'out') 1-2, 2-5, 5-6...

- Memory with playing cards (numbers to 10), prepare deck of cards first in small groups
- Number dictation using numbers or letters

- Drawing dictation (e.g. draw 3 pencils)

- Dot to dot (by dictation) - numbers or letters NOT in order (Internet Search “dot to dot printables”)

- Relays: Divide the class into two teams. Have one student from each team approach the blackboard. Call out a number and the first student to write the number on the board correctly scores a point for his / her team.

Color by number using English numbers and colors. Older children:

- Bingo - This is a comprehension exercise. The winner is the pupil who has understood the numbers, not the pupil who has the numbers you've called out. Tell students to quickly draw a Bingo card ( $4 \times 4$ cells) on a piece of paper and to randomly write in each square the numbers 0 to 20 , which they will mark when they understand the number that you then call out (remember to keep a list of the numbers as you call them out). The first pupil to have 4 numbers in a row is the first winner. The second winner is the first person to have marked all the numbers on his/her card (which the teacher checks). This can also be done with the alphabet and with larger numbers (the most difficult for comprehension being the numbers 30-50).

- Set up a 'shop' in the classroom, using empty containers, bottles, jars, etc. Write price tags for each item. Invite students to role-play dialogues in L2 using the items in the shop. Start with euros. Repeat with British or U.S. currency. Have the students convert the euro prices into pounds/dollars. Make paper money and coins. Teach the phrases: "Here's (5) pounds." and "Here's your change: (2) pounds, (10) pence."

- Measurements and conversions: Photocopy the following chart and give one to each pair of students. Give them only the first measurement and tell them to calculate the other quantities.

Length

1 inch $=2,54 \mathrm{~cm}$

12 inches $=1$ foot $=$

3 feet $=1$ yard $=\longleftarrow \quad \mathrm{cm}$

5280 feet $=1$ mile _ $\mathrm{m}$

1760 yards $=1$ mile _ $\mathrm{m}$

- Download a 12 inch ruler image from internet and print on heavy paper. Cut out and give one to each pair of students. Have them measure their desk, books, classroom, etc. in feet/inches and in centimeters, or have them convert from one to the other.

- Kids love to be measured so bring 4 or 5 tape measures in inches to school and have the students measure each other and convert their height into feet and inches.

- e.g. 63 inches = 5 foot 3 inches ( 5 ' 3”)

- Have students find out the height of their classmates and prepare a class graph, using feet and inches. Or have them convert from centimeters.

- Tell the students to invent questions about their school and classroom. E.g. How high is this classroom?, how wide?, how long?, how old?, and the school...? They should try and guess the answers 
and/or measure/research. Have them convert the numbers into feet and inches.

\section{- Capacity (Liquid)}

1 ounce $=30 \mathrm{cl}$. (approximately)

8 ounces $=1$ cup

2 cups $=1$ pint

16 fluid ounces $=1$ pint $\mathrm{cl}$

2 pints $=1$ quart $\mathrm{cl}$

4 quarts $=1$ gallon $\mathrm{cl}$

Try some recipes in L2 (e.g. pancakes - a favorite!).

\section{- Weight}

1 pound $(1 \mathrm{Lb})=0.4535924 \mathrm{Kg}-1 \mathrm{Kg}=2.2 \mathrm{lbs}$ (pounds)

14 pounds $=1$ stone $\mathrm{Kg}$

Have them convert their weight into pounds and stones. Make a chart.

This is also an excellent way to revise and increase fluency in using numbers.

\section{- Units of temperature Fahrenheit/Celsius}

Pure water is freezes at $32{ }^{\circ} \mathrm{F}=0{ }^{\circ} \mathrm{C}$ and boils at $212^{\circ} \mathrm{F}$

$=100{ }^{\circ} \mathrm{C}$ at $1 \mathrm{~atm} ; 68^{\circ} \mathrm{F}=20^{\circ} \mathrm{C}$ the conversion formula is: $C=\frac{5}{9}(F-32)$ or inversely as $F=\frac{5}{9} C+32$.

\subsection{Geography}

Most foreign language textbooks are full of cultural information of the countries where the language is spoken. Yet no-one considers the fact that what students will actually need is not the ability to describe London or New York in English, but to be able to talk about their OWN country in English because when they go abroad or speak to foreigners in L2 they will be asked about the country they come from.

A very effective project we have carried out with middle school children in the last few years to bridge this gap is to make a dynamic FACT FILE CHART for their country (to then later be compared with other countries they study!) in L2, e.g.:

\begin{tabular}{c}
\hline FACT FILE \\
Name: Italy \\
Population: \\
Size: \\
Capital: \\
Currency: \\
Language: \\
Flag: \\
Type of government: \\
Organization of government: \\
Head of government: \\
Climate: \\
Major cities/places to visit: \\
Animals: \\
Music: types: \\
Names: \\
Food and drink: \\
Sport: \\
Festivities: \\
Other:
\end{tabular}

The teachers using this chart have been amazed by the fact that the students are often not aware that certain customs/features of Italy are not universal. This is an excellent activity for exploring the pupils' own and different cultures.

Example recently completed by a class of 13 year olds:

Name: Italy = Repubblica Italiana/Italian Republic

Population: about 60 million; population density 198/km², 513/sq mi
Size: $301,340 \mathrm{~km}^{2} / 116,346$ square miles, divided into 20 Regions

Capital: Rome

Currency: Euro

Language: Italian

Flag: green, white and red

Type of government: Parliamentary Constitutional Republic

Organization of government: Parliament

Lower House: Chamber of Deputies (630 members), President: Laura Boldrini

Upper House: Senate (315 senators + 6 lifetime senators), President: Pietro Grasso

Head of government: Prime Minister: Matteo Renzi, President: Sergio Mattarella

Climate: Alpine in the north, Continental in the center/north, Mediterranean in the south and along the coast

Major cities/places to visit (with names different in English):

Rome, Florence, Naples, Milan, Turin, Venice, Genoa, Padua, Mantua,

Tuscany, Sardinia, Sicily, Mt. Etna, Mt. Vesuvius, Garda Lake

Animals: boar, marmot, mountain goat, wolf, deer, brown bear

Music: types: classical, opera, hip hop, rap, rock, pop Names: Emma, Max Pezzali, Elisa, Laura Pausini, Giorgia, Vasco Rossi, Jovanotti, Andrea Bocelli

Food and drink: pizza, pasta (lasagna, macaroni, noodles, ravioli, tortellini, gnocchi), olive oil, wine, tomatoes, grapes, cheese (parmesan)

Sport: football (GB)/ soccer (USA) =calcio

Other: cars: Ferrari, Fiat, Lancia

clothes/fashion: Gucci, Armani, Benetton, Roberto Cavallo

Festivities: Carnevale, Befana

Obviously, each of the above points can be expanded and developed by the teacher in L1 or L2.

Maps of the pupils' country in L2 should be placed alongside those in L1:

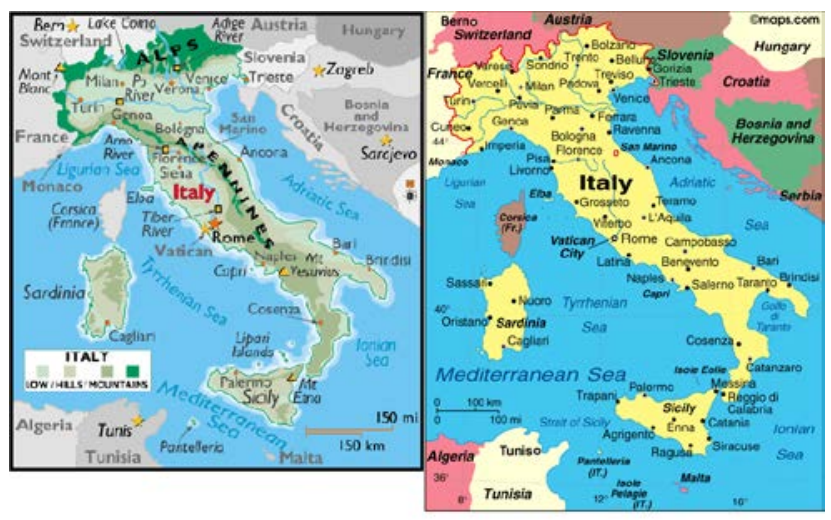

Using the cardinal points (north, south, east, west), describing their country becomes extremely easy: e.g. "Milan is north of Florence."

Another advantage of using L2 in Geography is that description is always in the present tense and therefore it can be widely applied even in the lower Primary School grades. Smart boards make it even more fun.

Smart Board instructions: drag the word to the correct place on the map. 


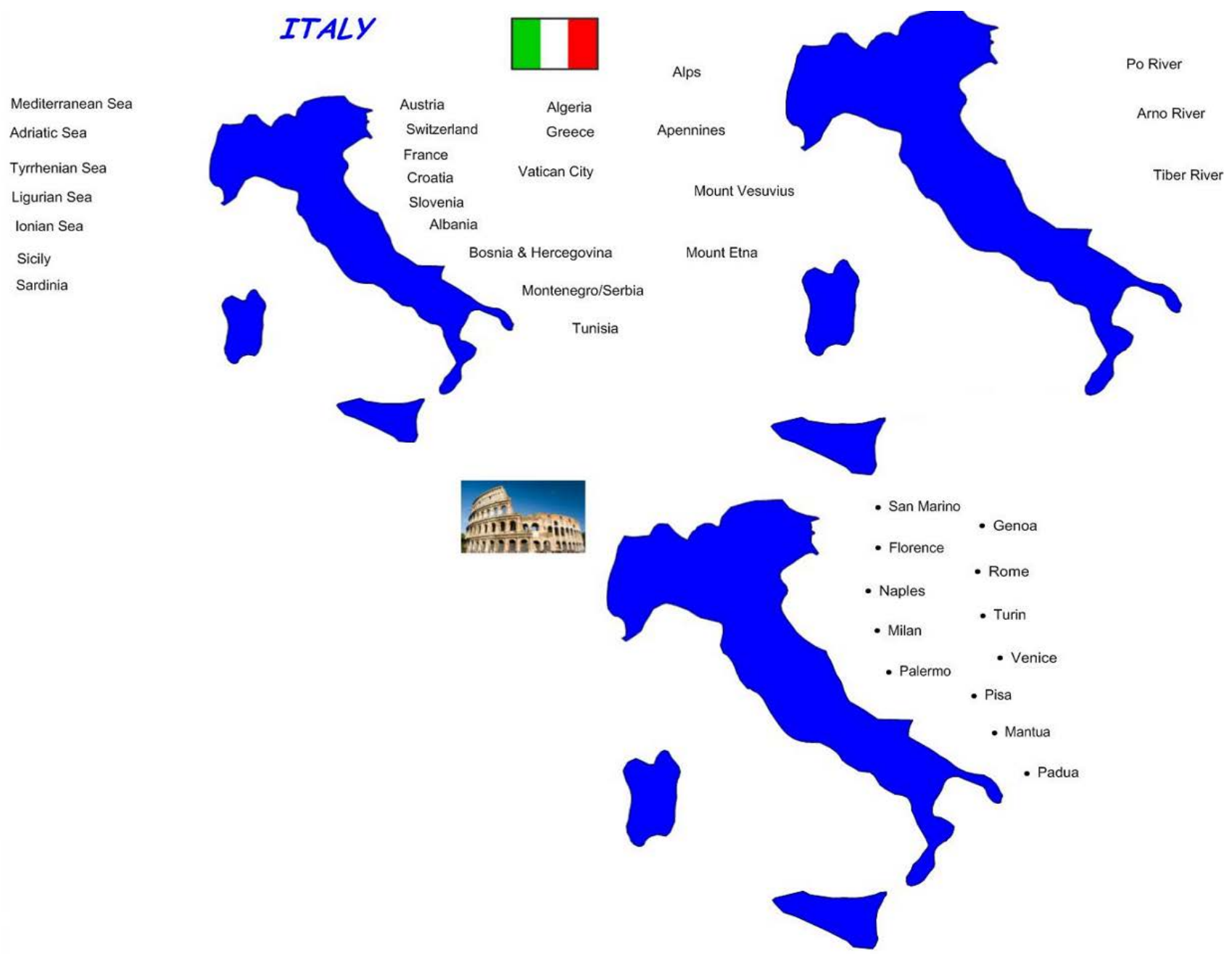

Conversational possibilities include:

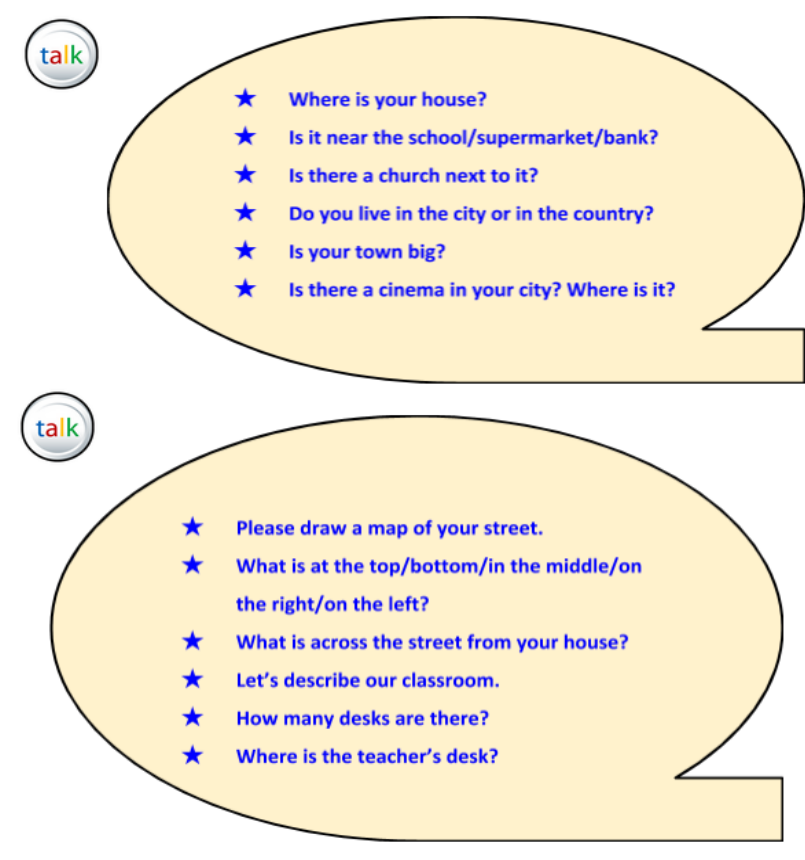

\subsection{CLIL with L1}

- An entertaining way to increase vocabulary in L2 is storytelling in L1 using picture gaps instead of words or omitting vocabulary that the children then add
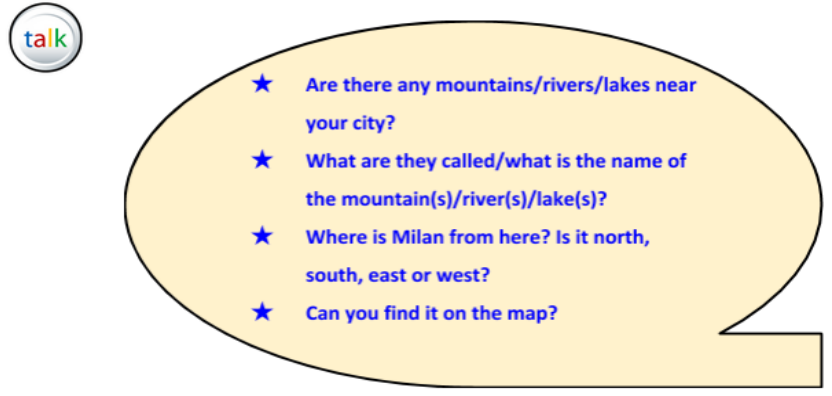

Interactive activities:

> http://www.wwp.greenwichmeantime.com/ interactive site on time zones.

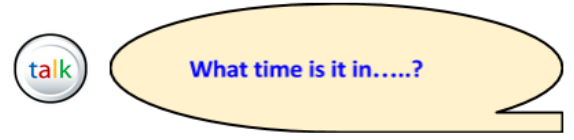

> http://www.bbc.com/weather/ interactive site on weather.
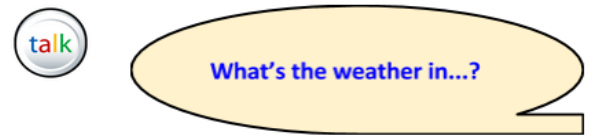

orally in English. Add new words each time you read/tell the story. For example:

“C'era una volta THREE BEARS, A MOMMY BEAR, A DADDY BEAR AND A BABY BEAR. Vivevano in una grande HOUSE in un bosco...." 
- Have older kids bring in signs in L2 that they see around their town and analyze the errors:

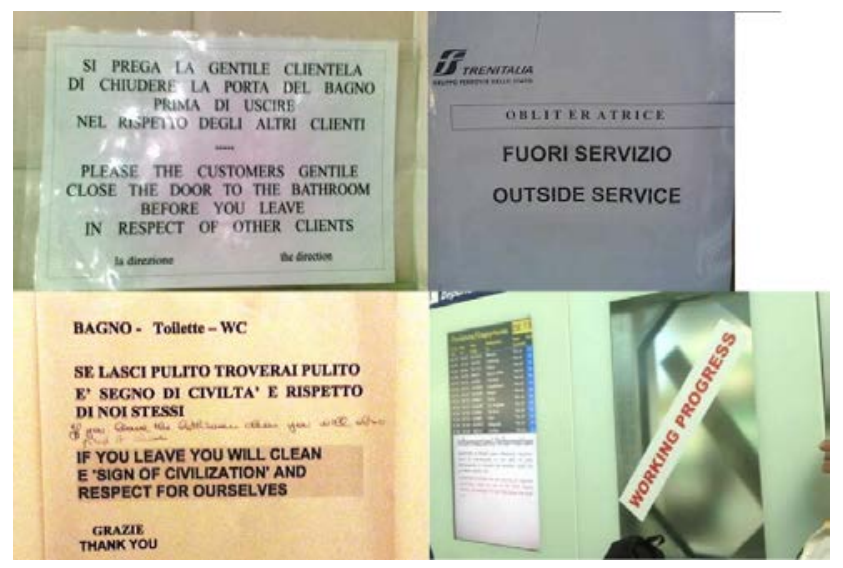

- Plan a school trip in L2 using the L2 version of websites:

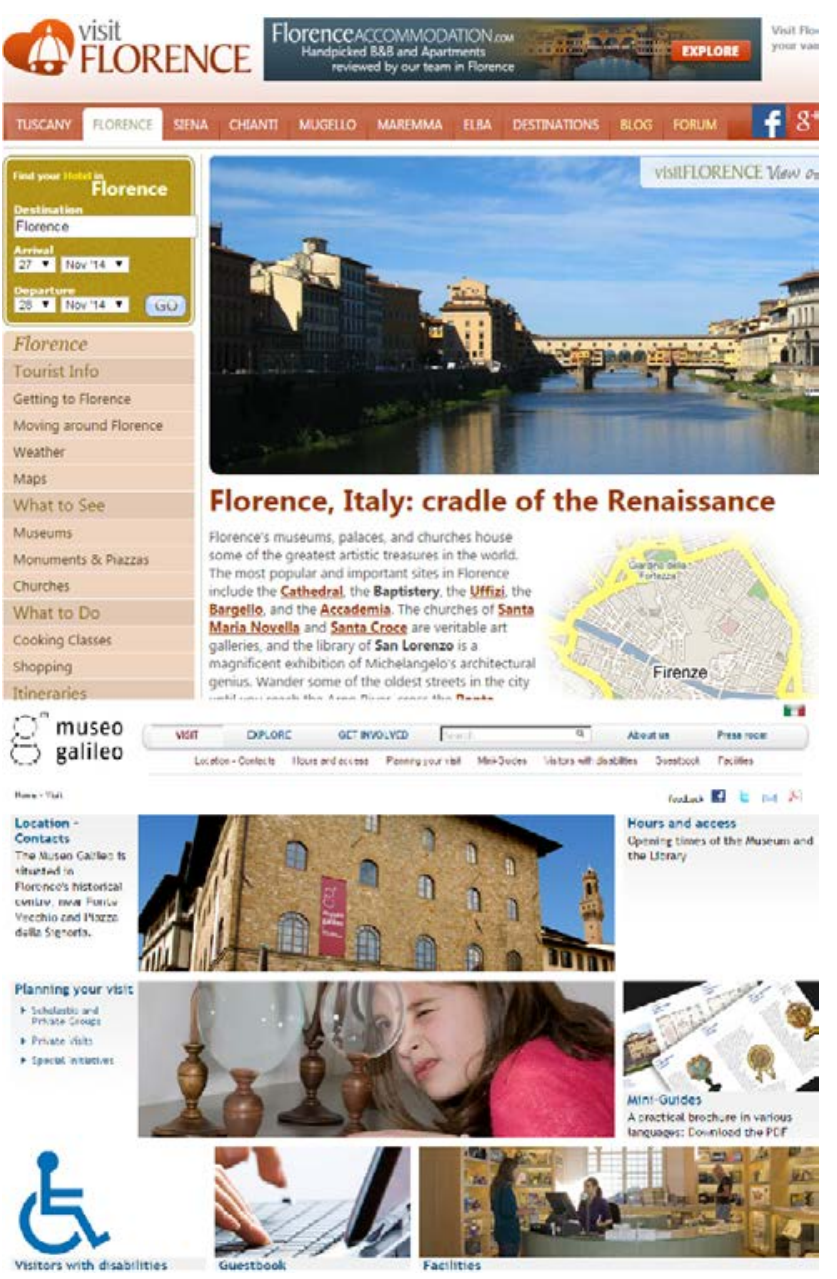

\subsection{CLIL with Art and Music -}

Draw a song: examples for small children:

- Old MacDonald had a farm: one group makes the large farm poster, other students make the animals, while singing they walk across the 'stage' with each animal. Sing in English and L1.

- Mary had a little lamb

- Hey Diddle Diddle

- Ten Little Indians/Tigers

Older children: Describe this painting in L2:

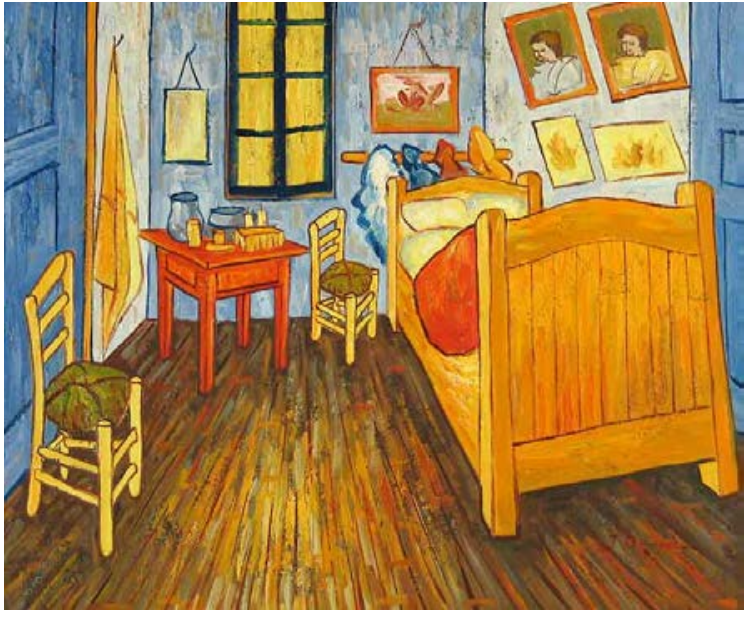

\subsection{CLIL with science}

- Develop a project on nutrition and healthy foods. The students could make a food pyramid poster for the classroom and write the names of all the different foods on it in English.

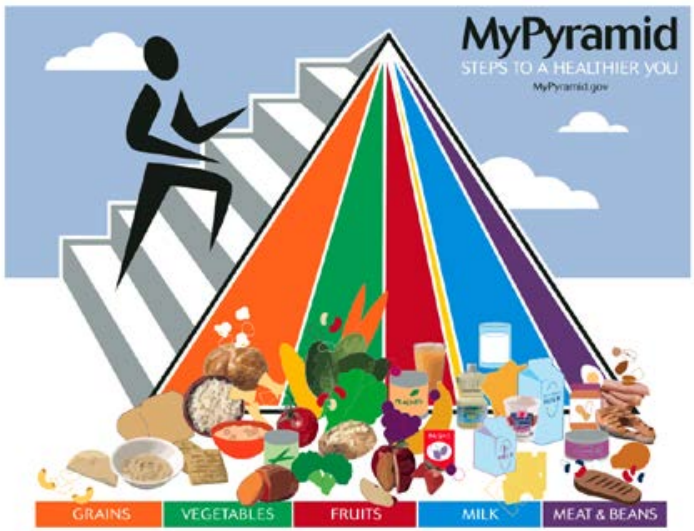

\section{Lunch or morning snack}

Names of food (use a Smart Board and draw a line from the name of the food to the picture; classroom vocabulary: please pass the bread, eat your apple, don't throw food, clean the table, put your plate here...)

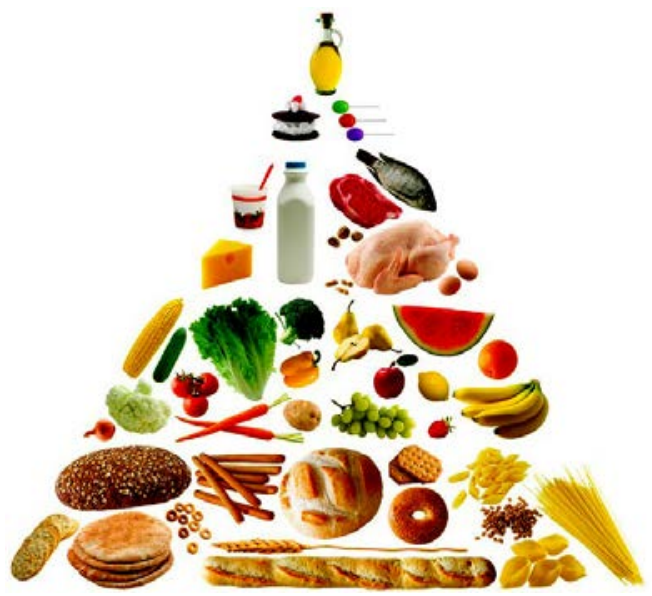

If your students eat lunch at school, help them to invent a school menu that they would like. However, they must choose only healthy foods!

\section{Water}




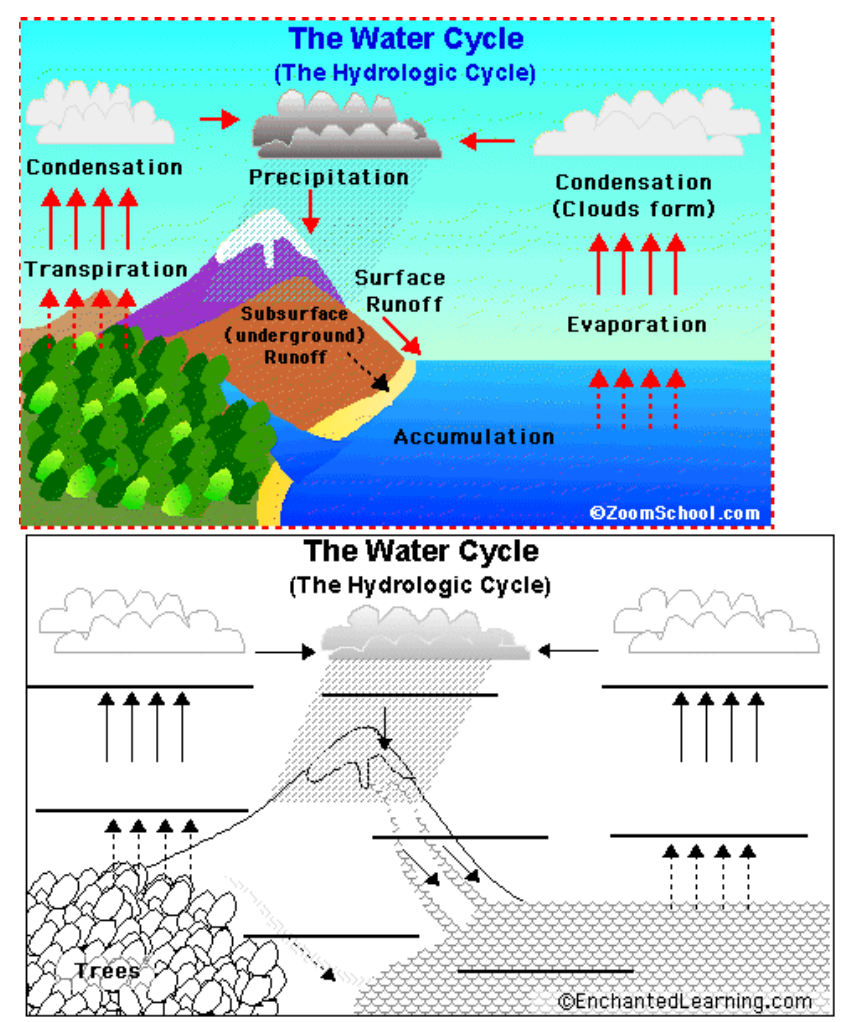

Older children:

- What is water?

- Where is it?

- Who needs water?

- What do we use water for?

- Why is there a problem with water?

Put these words next to the correct question:

People, animals, plants, lakes, glaciers, drinking, industry, agriculture, hydrogen, rivers, rain, pollution, cooking, personal hygiene, oceans, desertification, global warming, water sports, lack of freshwater, melting of ice caps, waste water $\rightarrow$ Conduct a survey on water usage

1. Estimate how much water you and your family use daily for the following activities: drinking, toilet flushing, washing the dishes, cooking, personal washing, washing clothes, gardening, cleaning

Use these estimates:

one glass $=1 / 3$ litre

one washing up bowl = 10 litres

one "flush" of the toilet $=10$ litres

one bath $=150$ litres

one shower $=30$ litres

Estimated daily water consumption for a family of..... = ....litres

2. Compare your chart with the rest of the class: Are the percentages similar? Where are the major differences?

How can you reduce your water consumption?

What activities could be stopped at times of severe water shortage?

Can you think of a method for re-using water that normally goes down the drain?

\section{Conclusion}

In conclusion, if we want our children to learn to communicate in L2 (which is what they will need in their later lives!), they have to start using it at an early age and for everyday language, as they do with their L1. Teachers in primary school classrooms can promote their learning by using English in all subject areas throughout the day, even in little five minute activities.

The results obtained so far by teachers who are adopting this method are extremely encouraging but the long-term goal is for all Italian primary school teachers to use L2 in their classrooms.

\section{Useful Web Sites on CLIL and for Classroom Materials in English}

- The author's website: https://sites.google.com/site/nbaileysite

- E-CLIL European Project: http://e-clil.uws.ac.uk/

- European Comenius Project: http://eclil4you.weebly.com/

- http://www.onestopenglish.com/clil

- Oxford University Museum of Natural Science: http://www.oum.ox.ac.uk/thezone/index.htm

- Primary English
http://www.primaryresources.co.uk/

Resources:

- For history materials and ideas visit at: http://www.bbc.co.uk/history/forkids/

- Kids Health website with materials on how the body works: http://kidshealth.org/kid/

- BBC schools website which has materials for all school subjects: www.bbc.co.uk/schools

- Channel 4 Teaching and Learning for Primary school subjects:

http://www.channel4learning.com/index.html

- Enchanted learning has pages for science: http://www.enchantedlearning.com/Home.html

- Woodland Primary School has history, geography, and science materials: http://www.woodlandsjunior.kent.sch.uk/

- Geography puzzles for children: http://www.yourchildlearns.com/mappuzzle/europepuzzle.html

- http://www.abcteach.com/

- http://www.sparklebox.co.uk/

- http://www.exploratorium.edu/ videos, activities for CLIL, science e art

- http://www.kidsfreesouls.com/grammarstories.htm

- - grammar through stories

- http://www.kidsfreesouls.com/grammarfun.htm

- www.englishraven.com - with online audio and video materials and links

- http://www.atozteacherstuff.com

- http://www.teachingenglish.org.uk/ - BBC

- www.primaryresources.co.uk - CLIL resources

- http://www.picsearch.com - Pictures to use for flashcards

- http://www.guinnessworldrecords.com - Guinness world records

- http://www.coastkid.org - anti-bully site

- http://www.bigeyedowl.co.uk/ - lots of activities

- http://www.webenglishteacher.com

- http://www.primaryresources.co.uk - CLIL for all subjects 
- http://www.teachingideas.co.uk/ CLIL for all subjects

- http://www.magickeys.com/books/index.html\#ya online books for children

- http://learnenglishkids.britishcouncil.org - especially songs and topics with audio and video

- www.eslflashcards.com flashcards + lots of links

- www.flickriver.com infinite number of photos, downloadable

- http://school.discoveryeducation.com - resources and puzzlemaker

- www.learn-english-today.com/wordgames.html easy and printable worksheets

\section{References}

[1] Asher, J. (1969). The Total Physical Response Approach to Second Language Learning. The Modern Language Journal, 53 (1), 3-17. Retrieved from: http://www.jstor.org/discover/10.2307/322091?sid=211059613728 73\&uid=2\&uid=4\&uid=3738296

[2] Ball, P. (2013). Activity types in CLIL. Retrieved from: http://www.onestopenglish.com/clil/methodology/articles/articleactivity-types-in-clil/500800.article

[3] British Council (2014). CLIL POLICY AND PRACTICE: Competence-based education for employability, mobility and growth. Como, Italy. Retrieved from: http://www.britishcouncil.org/sites/britishcouncil.uk2/files/clil_rec ommendations_august_14_pdf.pdf

[4] Clegg, J. Planning CLIL lessons. Retrieved from: http://www.onestopenglish.com/clil/methodology/articles/articleplanning-clil-lessons/500472.article

[5] Coonan, M.C. (2014). I principi di base del CLIL. Fare CLIL, I Quaderno della Ricerca, 14, Torino: Loescher, 17-35. Retrieved from: http://clil.loescher.it/quaderno-della-ricerca-fare-clil.n2955

[6] Coonan, M.C. (2014). Le basi glottodidattiche del CLIL. La Ricerca, 6, Torino: Loescher, 17-20. Retrieved from: http://www.laricerca.loescher.it/istruzione/905-obiettivo-clil.html
[7] Council of Europe (2011). Common European Framework of Reference for: Learning, Teaching, Assessment (CEFR). Retrieved from: http://www.coe.int/t/dg4/linguistic/cadre1_en.asp

[8] Coyle D., Hood P., Marsh D. (2010). Content and Language Integrated Learning. Cambridge: Cambridge University Press.

[9] European Commission (2003). Communication from the Commission to the Council, the European Parliament, the Economic and Social Committee and the Committee of the Regions. Promoting Language Learning and Linguistic Diversity: an Action Plan 2004-2006. Retrieved from: http://eurlex.europa.eu/legal-content/EN/TXT/?uri=CELEX:52003DC0449

[10] Graddol D. (2006). English Next. British Council Publications.

[11] Marsh, D. (2002). Content and Language Integrated Learning: The European Dimension-Actions, Trends and Foresight Potential. Retrieved from: http://europa.eu.int/comm/education/languages/index.html

[12] Marsh, D., Marsland B. \& Stenberg K. (2001). Integrating Competencies for Working Life. Jyväskylä: University of Jyväskylä.

[13] Ministero dell’Istruzione, dell'Università e della Ricerca (2012). Indicazioni nazionali per il curricolo della scuola dell'infanzia e del primo ciclo d'istruzione, Decree 16 November 2012 n.254, in effect since 20 February 2013. Retrieved from: http://www.indicazioninazionali.it/documenti_Indicazioni_nazion ali/DM_254_201_GU.pdf

[14] Ministero dell'Istruzione, dell'Università e della Ricerca (2014). The Italian Education System. I Quaderni di Eurydice, 30. Firenze: Indire.

[15] Retrieved from: http://www.indire.it/eurydice/content/index.php?action=read_cnt\& id_cnt $=15135$

[16] Swain M. (2006). Languaging, Agency and Collaboration in Advanced Second Language Proficiency. In Byrnes H. (Ed.), Advanced Language Learning: The Contribution of Halliday and Vygotsky, 95-108. London-New York: Continuum.

[17] Retrieved from: http://lrc.cornell.edu/events/past/20112012/papers11/swain.pdf 